\title{
Nearly one third of adults in the 'healthy' BMI range are at early cardiometabolic risk according to their waist-to-height ratio
}

\author{
M. Ashwell ${ }^{1}$ and S. Gibson ${ }^{2}$ \\ ${ }^{1}$ Ashwell Associates, Ashwell, Herts., SG7 $5 P Z$ and \\ ${ }^{2}$ Sig-Nurture Ltd, Guildford, Surrey GU1 $2 T F$.
}

The National Institute for Health and Care Excellence (NICE) has recently acknowledged the potential value of waist-to-height ratio (WHtR) as a proxy for central adipose tissue and a marker for 'early health risk' and calls for further studies $\left.{ }^{(1)}\right]$. We used recent data (2016) from the Health Survey for England (HSE) to explore the impact of WHtR in adults in the 'healthy' BMI range i.e. BMI between 18.5 and $25 \mathrm{~kg} / \mathrm{m}^{2}$.

We compared levels of three risk factors: HbA1c, TC:HDL ratio, and systolic blood pressure (SBP), according to WHtR. Anthropometric measurements (weight, height, waist circumference) were taken by trained nurses. Waist circumference (WC) was measured at the midpoint between the lower rib and the upper margin of the iliac crest. Data were weighted to account for unequal selection and non-response to the nurse visit. Differences in risk factors were tested using GLM adjusted for age, sex and BMI.

The percentage of adults in the 'healthy' BMI range, but with WHtR $>=0.5$, was $31 \%$ (males $36 \%$, females $27 \%$ ). Compared with adults who had WHtR $<0.5$, these people were significantly older, (mean $54 \mathrm{vs} .37 \mathrm{yr})$ heavier $(67 \mathrm{vs} .64 \mathrm{~kg})$, shorter $(167 \mathrm{vs} .170 \mathrm{~cm})$, had higher BMI (23.7 vs. $\left.22.0 \mathrm{~kg} / \mathrm{m}^{2}\right)$ and were more likely to be male $(52 \%$ vs $43 \%)($ all $\mathrm{P}<0.001)$. Most importantly, levels of the three risk factors were significantly higher in those with a high WHtR (Table). Results were the same for both sexes (data not shown). After adjustment for age, sex and BMI in fully adjusted models with interactions, differences in the three cardiometabolic risk factors remained statistically significant: (HbAlc $+1.2 \mathrm{mmol} / \mathrm{ml}$; TC:HDL ratio +0.5 ; $\mathrm{SBP}+3.4 \mathrm{mmHg}$ ).

\begin{tabular}{|c|c|c|c|c|c|c|c|c|c|}
\hline & & \multicolumn{4}{|c|}{ WHtR unadjusted } & \multicolumn{4}{|c|}{ WHtR adjusted for age, sex and BMI } \\
\hline & & $<0.5$ & $0.5+$ & difference & $\mathrm{P}$ & $<0.5$ & $0.5+$ & difference & $\mathrm{P}$ \\
\hline $\begin{array}{l}\mathrm{HbAlc} \\
(\mathrm{mmol} / \mathrm{ml})\end{array}$ & Mean & 34.6 & 37.4 & 2.8 & $<0.0001$ & 36.0 & 37.2 & 1.2 & $<0.001$ \\
\hline $\begin{array}{l}\text { TC: HDL } \\
\text { ratio }\end{array}$ & Mean & 3.0 & 3.6 & 0.6 & $<0.0001$ & 3.1 & 3.6 & 0.5 & $<0.0001$ \\
\hline SBP (mm & Mean & 116.7 & 127.1 & 10.4 & $<0.0001$ & 121.3 & 124.7 & 3.4 & $<0.001$ \\
\hline
\end{tabular}

$\mathrm{Hg})$

Mean levels of cardiometabolic risk factors according to WHtR (boundary value 0.5 ) in adults in the 'healthy' BMI range. $\mathrm{n}=1182(\mathrm{HbA1c})$; $\mathrm{n}=1117$ (TC:HDL); $\mathrm{n}=1351(\mathrm{SBP})$

The results are consistent with those from other studies, which have also reported that adults in the 'healthy' BMI range but with WHtR $>=0.5$, have increased levels of cardiometabolic risk factors ${ }^{(2-4)}$. WHtR has the potential to be a simple indicator of the cardiometabolic risks associated with central adipose tissue. Its use in early screening would give greater opportunity for a substantial proportion of adults (nearly one third), who are in the 'healthy' BMI range but have high WHtR, to receive further screening ${ }^{(5)}$.

NICE should therefore consider the efficacy of using WHtR as an alternative to its BMI/WC matrix in primary care. Public health bodies should consider spreading the simple message to all age groups: "Keep your waist to less than half your height".

1. National Institute for Health and Clinical Excellence. (2018) https://www.nice.org.uk/guidance/ph46/documents/surveillance-review-proposal (accessed October 2018)

2. Ashwell M, Gibson S. BMJ Open. 2016;6(3):e010159.

3. Thaikruea L, Thammasarot J. Sci Rep. 2016;6:37100. doi:10.1038/srep37100.

4. Liu PJ, Ma F, Lou HP, Zhu YN. Asia Pac J Clin Nutr. 2017;26(4):692-7. doi:10.6133/apjen.052016.08.

5. Ashwell M. Adv Obes Weight Manag Control. 2017;7(2):255-257. doi: 10.15406/aowmc.2017.07.00191. 